\title{
Edgar Quinet e o romantismo
}

\section{Arlenice Almeida da Silva}

Resumo: A obra de Edgar Quinet gira em torno de três temáticas: a primeira concentra-se em abordagens históricas, com forte acento religioso: Le génie des religions, Les jésuites, L’ultramontanisme, L'essai sur la vie de Jésus Christ etc. Um segundo núcleo trata exclusivamente de temas políticos como Les révolutions d'Italie e La campagne de 1815. Uma última dobra se insinua em obras que privilegiam os temas literários, como Vie et mort du génie grec e La poésie épique, culminando na produção ficcional do autor, especialmente em Ahasvérus. Palavras-chave: Edgar Quinet, romantismo francês, Ahasvérus.

Abstract: Edgar Quinet's work revolves around three themes. The first one focuses on historical approaches with a strong religious accent: Le génie des religions, Les jésuites, Lessai sur la vie de Jésus Christ etc. The second one deals exclusively with political issues as Les révolutions d'Italie and La campagne de 1815. The last one is noticed in works that emphasize literary themes, as Vie et mort du génie grec and La poésie épique, culminating in the author's fictional creation, especially in Ahasvérus. Keywords: Edgar Quinet, French Romanticism, Ahasvérus. 
O Gênio é como Ahasvérus... solitário

A marchar, a marchar no itinerário

Sem termo do existir.

Invejado! A invejar os invejosos.

Vendo a sombra dos álamos frondosos...

E sempre a caminhar... sempre a seguir...

Pede uma mão de amigo - dão-lhe palmas:

Pede um beijo de amor - e as outras almas

Fogem pasmas de si.

E o mísero de glória em glória corre...

Mas quando a terra diz: - "Ele não morre”...

Responde o desgraçado: - "Eu não vivi!"

Castro Alves

Escritos em 1868, os versos acima fazem parte do poema intitulado "Ahasvérus e o gênio". Trata-se de uma homenagem do poeta baiano à poesia épica de Edgar Quinet, tida como uma notável e instigante apropriação literária da lenda do “judeu errante, do homem que não morre". Antonio Candido e Jamil Almansur Hadad confirmam a presença do poeta francês entre nós, observando que o poema Ahasvérus exerceu forte influência em poetas como Castro Alves ou Álvares de Azevedo. Seria apenas um detalhe na formação dos poetas, ou uma vinculação significativa? Em todo caso, seria interessante localizar e dimensionar a presença de Edgar Quinet na literatura romântica brasileira. Álvares de Azevedo, em um artigo sobre Alfredo de Musset, chega a afirmar que Ahasvérus era "porventura o poema de mais imaginação que tenhamos lido”. Ainda segundo Antonio Candido, o épico de Quinet, ao "corporificar toda a utopia libertária do século", simbolizando a "luta eterna da humanidade em busca de redenção e justiça", possibilitou à poesia de Castro Alves força histórica.

Há [diz Antonio Candido] em Castro Alves o sentimento da história como fluxo, e do indivíduo como parcela consciente deste fluxo. Por isso logrou uma visão larga e humana do escravo. [...] O movimento incessante de Ahasvérus, cuja personalidade vai se 
redefinindo ao contato das vicissitudes por que passa, corresponde ao movimento perene dos povos, superando-se igualmente sem parar pelo "batismo luminoso das grandes revoluções".

Quem foi Edgar Quinet? Qual sua importância para o romantismo francês? Como interpretar o silêncio em torno do nome de Quinet? Como testemunha e ator de três revoluções, a de 1830, de 1848 e de 1870 , ele foi um homem do século xIx; um respeitado professor universitário, um académicien, mas também um atuante deputado republicano e um dos primeiros insurretos, em fevereiro de 1848, a penetrar nas Tulherias de fuzil nas mãos. Além disso, há um consenso entre os historiadores, que veem em Quinet, ao lado de Benjamin Constant, um dos principais nomes do republicanismo francês do século XIX, de modo que o pesquisador percebe que não se pode falar do campo histórico e literário do século XIx francês omitindo Quinet. Corretamente falando, ele não foi totalmente esquecido, pois seguidas vezes aparece ao lado de Michelet, marcando a produção historiográfica do século, mas quase sempre como uma sombra e não como uma personalidade independente. Em outros momentos, ele desponta ao lado de Victor Hugo, mas como um exemplo de literatura de boas intenções e pouco público. Em outros, ele é colocado no grupo dos filósofos como Victor Cousin, mas aqui também sem produzir ao menos um "eclético" sistema. Poderíamos, enfim, anotar em tom lamentoso que o que marca sua obra seria uma espécie de atuação em penumbra, num segundo plano. ${ }^{2}$ Maurice Agulhon, no prefácio escrito para a excelente biografia sobre Quinet, de Laurence Richer, ${ }^{3}$ procura justificar o papel secundário de Quinet, afirmando que ele viveu em um período dominado por duas unanimidades, Michelet e Victor Hugo. Sem eles, o século xIX seria de Quinet. ${ }^{4}$

Em primeiro lugar, Quinet não foi apenas um historiador. O mais correto seria vê-lo como um "homme de lettres", um philosophe, mas talvez o termo já pareça um pouco anacrônico no século XIX. A marca central do pensamento de Quinet, a despeito disso, é a vasta problemática que insiste em costurar filosofia, história e literatura. Jamil Almansur. Revisão de Castro Alves. v. 3, p. 24-5. uma única vez.

3 1999.

Cf. AGULHON, Maurice. 1848 ou o Aprendizado da república. São Paulo: Paz e Terra, 1991. 
Tal abrangência, hoje considerada improdutiva, era, no XIX de Quinet, estimulada e buscada; um elemento essencial da definição do intelectual. Espírito generalizante e ao mesmo tempo poético, ele se aproxima mais das grandes visões de conjunto, das considerações filosóficas e menos de estudos técnicos e detalhados. O século XIX produziu, assim, com Quinet, pensadores superlativos, seja pela abrangência enciclopédica dos conteúdos, seja pela quantidade dos volumes apresentados ao público. Se Michelet pôde ostentar seus sessenta volumes, Quinet não fica a dever com os seus mais de trinta volumes. É deste estilo abundante que brota uma linguagem própria, ou seja, uma escritura na qual o excessivo não é enfadonho, mas faz sistema, articulando disciplinas e temáticas.

Assim, podemos observar que o núcleo central de sua obra gira em torno de três temáticas. A primeira concentrada em abordagens históricas, com forte acento em temas religiosos: Le génie des religions, Les jésuites, L’ultramontanisme, Lessai sur la vie de Jésus Christ, Le christianisme et la Révolution Française e La Révolution, em um quadro teórico que poderíamos nomear de crítica histórica e religiosa. Mas um segundo núcleo desdobra-se do primeiro tratando de temas exclusivamente políticos como Les révolutions d'Italie, La campagne de 1815. E uma última dobra se insinua em obras que privilegiam os temas literários, como Vie et mort du génie grec, La poésie épique, e culminam na produção ficcional do próprio Quinet, especialmente em Ahasvérus.

Assim, mergulhando nas controvérsias da época, é inevitável investigar, entre outras coisas, se Quinet era um autor romântico, combinando uma consciência estética com consciência histórica, ou se seu romantismo anunciava o moderno, ou refugiava-se na tradição. Em todo caso, há um consenso entre os autores que lhe querem bem sobre sua imprudência. $\mathrm{O}$ excesso e as afirmações dramáticas e definitivas atraíram para si o estigma de inconsequente e temerário. Heine dirá a propósito, com certa ironia, que sua alma era na verdade alemã. Lucien Febvre, ao contrário, que havia algo de falso em sua escrita exaltada e no arrebatamento que provocava. ${ }^{5}$ Paul Valéry generalizou semelhante diagnóstico para todo o romantismo: "envenenado por lendas e histórias, um verdadeiro romântico é acima de tudo um ator. A simulação, o exagero, a facilidade em que caem todos os que visam apenas produzir sensações imediatas, são os vícios desse momento das artes" ${ }^{6}$ 
A sua decepção com o ecletismo - movimento filosófico liberal, composto por Victor Cousin, Théodore Jouffroy e Royer-Collard - não foi menor e contribuiu para a radicalização de seu pensamento. Até 1825, Quinet acompanhava Victor Cousin e seu ecletismo espiritualista. Com uma atuação corajosa e incisiva na École Normale, um estilo arrebatador, falando abertamente de religião e política, Cousin estimulava jovens como Quinet e Michelet, defendendo uma filosofia ligada ao tempo e à história.? Ora, o ecletismo - uma imbricação entre o criticismo de Kant, o hegelianismo e a filosofia escocesa, com Thomas Reid e Dugald Stewart - prometia não só combinar vários sistemas filosóficos, mas julgar as doutrinas, tomar emprestado o que nelas havia de comum e verdadeiro, negligenciar o que definiam como falso, deduzindo daí uma teologia, uma estética e uma moral. Contudo, lentamente, este pensamento acaba na valorização de certa psicologia e no repúdio ao sensualismo de Condillac, considerado um dos responsáveis pelos excessos da Revolução. A filosofia eclética torna-se, aos olhos de Quinet, cada vez mais professoral, engessada, afastando-se de sua finalidade republicana; de inspiradora do sistema educacional, ela se torna uma pedagogia oficial formadora dos estadistas e funcionários de Estado. Posicionando-se contra a filosofia do século XVIII e contra a Revolução Francesa, o ecletismo tornara-se, para Quinet, a "filosofia da Restauração", abandonando a promessa de ser um pensamento crítico e não conseguindo, assim, explicar nem mobilizar o presente. Diante da Revolução de 1830, o ecletismo capitula definitivamente, transformando-se em uma filosofia institucionalizada, voltada para a legitimação do poder.

No artigo de 1831, intitulado "De la Révolution et de la philosophie", Quinet constata a falência geral da filosofia de sua época por não orientar mais a ação política. "A política entrou em um estado de hibernação", diz ele; o presente indica uma era de "apostasia recente" na qual a filosofia se transformou em letra morta: meras palavras eloquentes. "Como agora, reitera o autor, toda a história parece suspensa e muda e a resignação às misérias é a única coisa que aparece entre os povos, a filosofia não sabe mais procurar e fundamentar o presente; sua característica é a de não ter nenhum pressentimento do amanhã."

O desapontamento com a política da década de 1830 e as dificuldades de inserção no fechado mundo acadêmico - ele será nomeado professor de literatura em Lyon em

No curso de filosofia ministrado em 1828, Cousin afirmou: "O ecletismo é a filosofia necessária do século, pois é a única que está conforme a sua necessidade e ao seu espírito; e todo o século realiza uma filosofia que o representa". COUSIN, Victor. Cours de philosophie. Paris: Fayard, 1991, p. 364. 
1839, e só em 1841 será indicado para a cadeira de literatura meridional no Collége de France - colocam Quinet exclusivamente no campo da literatura. São anos de indefinição e angústia, nos quais ele é afetado por uma espécie de enfermidade, que ele nomeia de "mal de l'attente". A cura vem da própria literatura e da "tentação da Idade Média”, como boa parte do movimento romântico, ao dedicar-se à recuperação e divulgação de um manuscrito épico do século XII, o Perceval de Chrétien de Troyes. Em seguida, volta-se definitivamente para a produção ficcional, e o resultado é o monumental Ahasvérus, um longuíssimo poema épico, escrito principalmente no refúgio de Certines, sua terra natal, e publicado em 1832. As expectativas do jovem Quinet são exageradas, pois espera alcançar, com esse poema épico, notoriedade, respeito e glória. Em uma carta escrita a Michelet, em janeiro de 1832, Quinet avisa ao amigo que Ahasvérus avançava: "Je sens bien que si je fais quelque chose de passable dans ma vie, ce sera cela". 9

De tal forma que, nos anos 1830, Quinet é mais literato que filósofo ou historiador, o que contribuirá para o rótulo de autor romântico, que lhe será imposto pela primeira recepção crítica de sua obra. Ora, alguns traços românticos são perceptíveis, mas nunca exclusivamente. De um lado, ele pode ser considerado romântico pela importância que atribui à poesia - como os principais representantes dessa tendência -, corroborando com a renovação e promoção do poeta e da literatura à guia e intérprete do novo mundo espiritual que sai da Revolução. A "revolução romântica", efeito direto da mutação política, pode ser caracterizada, entre outros elementos, por essa defesa de um sacerdócio poético, por meio da afirmação de um poder espiritual laico, ou seja, por uma consagração do poeta sem precedentes históricos, que acompanha a aurora de uma nova época. ${ }^{10}$ Por outro lado, não se encontram em Quinet as conhecidas marcas das batalhas formais contra a tradição clássica, como em Victor Hugo, nem o sentimentalismo subjetivo, a efusão do eu, como em Lamartine, que marcará boa parte do movimento literário, tampouco a religiosidade do romantismo católico de um Chateaubriand. Ao contrário, em suas obras e reflexões estéticas encontramos marcas de uma heterodoxia, e uma especial e acentuada revalorização do gênero épico, ou seja, uma produção que se debruça na pesquisa e modernização das possibilidades narrativas na poesia. Explorando a narrativa, ele redimensiona 
não só o papel da literatura, mas também o da história e, especialmente, da poesia épica, gênero, aliás, considerado frágil, segundo ele, entre os franceses. ${ }^{11}$

Em 1833, como vimos, surge o poema épico Ahasvérus; em 1836, ele publica um longo poema épico sobre um mito histórico, Napoleão Bonaparte, e em 1838, outro drama épico intitulado Prométhée. De tal forma que, nessas obras, Quinet participa da revalorização da epopeia que, da Palingénésie de Ballanche, de 1803, à Légende des siècles, de Hugo, de 1859, dominou o cenário do romantismo na primeira metade do século XIX. Em 1828, sob forte influência de Herder, Quinet esboça anotações para uma história das tradições épicas; material posteriormente publicado sob o título "De l’origine des dieux", no qual caracteriza pela primeira vez a epopeia moderna:

[...] agora que o homem dispõe dos anais da humanidade como Homero dispunha dos do povo grego, que ele escolheu a unidade da história e da natureza, aproximando os seres reais através dos séculos, em uma via maravilhosa em direção ao infinito, que estas cenas se sucedem e se encadeiam não mais nas sombras do inferno, do purgatório ou do paraíso da Idade Média, mas em um espaço ilimitado, brilhante de uma luz plena, agora ele pode atingir a forma possível e necessária da epopeia no mundo moderno. ${ }^{12}$

A conjunção do tema da Revolução com a revalorização do gênero épico é o que permite a Quinet dizer o mundo que sai da Revolução, isto é, exprimir sua "modernidade". A dicção é romântica, mas em formato impuro: a forma artística é orgânica, revelada a partir do interior mais espiritual do artista em contato com a natureza. Mas um orgânico que se constitui também a partir do externo, isto é, da história. A poesia é eco e exortação; é militante, um canto que acompanha as lutas públicas. É o que se pode perceber em Ahasvérus, seu melhor poema, que trata do problema da execução moderna do sagrado, combinando elementos do drama e da epopeia,

É interessante confrontar o argumento de Bénichou com o de G. Lukács. Em sua obra O romance histórico, de 1936, Lukács procura demonstrar que o romantismo surge no meio de uma luta ideológica sem precedentes sobre a interpretação da Revolução Francesa. A disputa literária resulta em duas concepções da história e duas correntes literárias: a primeira é reativa, nomeada de romantismo liberal, e se afirma contra a memória da revolução, pela defesa apologética da Idade Média, apesar de defender mudanças progressistas, concretizadas pela mesma Revolução. A segunda corrente, que vai de Goethe a Stendhal, é de matriz iluminista, pois busca não só afirmar a Revolução como conservar e realizar concepções herdadas do século XVIII, figurando, assim, o presente como história. G. Lukács, Le roman historique. Paris: Payot, 1965, p. 67-95.

QUINET, Edgar. Oeuvres complètes, tomo III. Paris: Pagneire Librarie-Editeur, 1857. 
em uma escrita poético-filosófica que lhe parece ser o instrumento adequado para a atualização do gênero. A obra em diálogos, monólogos e coro é uma forma variante do "mistério" em vigor na estrutura da dramaturgia medieval ${ }^{13}$ - estilo renovado pelo romantismo de Byron na Inglaterra e de Vigny, na França. ${ }^{14}$ Nesse poema, composto em uma estrutura dividida em quatro grandes jornadas, Quinet apropria-se da lenda do judeu errante para figurar a sucessão dos tempos e o desenvolvimento da história, ou seja, para encenar o "espetáculo" da tragédia da história do mundo. Aqui o poeta se faz historiador ao resgatar a seu modo e por meio de seu verbo a relação entre o divino e o histórico. Já no prólogo, o autor adverte tratar-se de um mistério terrível, de difícil narração; uma "longa história que oprimiu sempre seu próprio criador". Tudo indica que intencionalmente a estrutura da obra assinale um desequilíbrio. As partes são desiguais, seja na concentração temporal, seja no efeito dramático. Na primeira jornada, intitulada "Criação", é figurada uma conjunção de teogonia e cosmologia, numa narrativa demasiadamente concentrada sobre o nascimento dos deuses, do mundo e de seus principais elementos: o oceano, um pássaro, um peixe, uma serpente apresentam-se como divindades e, nessa condição, louvam as belezas e maravilhas da natureza. Em seguida, falam os primeiros povos, as primeiras cidades. Contudo, a harmonia inicial da criação é rapidamente suplantada por um conflito entre as cidades, na forma de uma disputa entre os deuses para medir força e superioridade. Abruptamente, por meio de uma condensação temporal ainda maior, a trama é deslocada para Jerusalém, no momento em que os reis magos encontram o "prometido", a criança que se anuncia como o deus superior a todos os outros já existentes; momento no qual o politeísmo rende homenagem, não só ao monoteísmo, mas especialmente à figura do Cristo encarnado em um homem. Assim, a criação do mundo desemboca no surgimento do Cristianismo e sua promessa de redenção e de recomeço; no movimento pelo qual o deus jovem supera a cansada religião oriental. Entre a primeira e a segunda jornada há um entreato composto por uma deslumbrante dança dos demônios, de forte apelo imagético, na qual em um movimento inverso é ironizada a pretensão do cristianismo de renovar o mundo, por meio da encarnação

Os mistérios medievais eram peças teatrais religiosas, influenciadas por tendências góticas que misturavam misticismo e realismo. Na França, os mistérios adquiriram forte carga lírica, no século XIV, com Miracle de Théophile, de Rutebeuf, e a Passion, de Didot.

14 Byron publica Cain, a mystery, em 1821, e "Heaven and earth", em 1823, ambos considerados os melhores exemplos de adaptação dos "mistérios" medievais para o século XIX. Vigny, fortemente influenciado pelo gênero, publica, em 1824,"Eloa". 
do divino em um homem. Belzebuth, por exemplo, procurando desmascarar a farsa, interroga: "a eternidade, enlouquecida, brincava em uma divina comédia, na qual ele era o único personagem?". 15

Assim, desmistificando, por meio de recursos de aproximação e de distanciamento, Quinet conduz a trama indiretamente para a segunda jornada, intitulada a "Paixão", o momento da morte e sofrimento de Cristo, especificamente para o instante do encontro entre Ahasvérus, o homem, e Cristo, a divindade encarnada. $\mathrm{O}$ diálogo é cortante e violento: Cristo pede água, Ahasvérus nega; Cristo pede ajuda para carregar a cruz, depois um abrigo contra o sol, e um lugar para descanso, e tudo lhe é negado. Diante das sucessivas recusas, do não reconhecimento da divindade, e, por fim, da expulsão por Ahasvérus do estranho invasor de sua casa, Cristo lhe responde:

\author{
Pourquoi l'as-tu dit Ahasvérus? C'est toi \\ qui marcheras jusqu'au jugement dernier, \\ pendant plus de Mille ans. Va prendre tes \\ sandales et tes habits de voyage; partout \\ où te passeras, on t'appellera: le juif errant. [...] \\ Tu seras l'homme qui ne meurt jamais. Moi, je vais \\ à Golgotha; toi tu marcheras de ruines \\ en ruines, de royaumes en royaumes, sans \\ atteindre jamais ton Calvaire. ${ }^{16}$
}

A maldição lançada sobre Ahasvérus fará dele um solitário, o judeu errante que, acompanhando as desventuras do mundo e da história, encontrará tão somente dor e sofrimento. Para Quinet, a história da humanidade a partir daí segue um sentido fatal, trágico, marcado por declínios, desmoronamentos, mortes, guerras, invasões, lágrimas. A morte de Cristo vem acompanhada de uma espécie de tragicidade incontornável, como se a maldição de Ahasvérus atingisse a humanidade inteira. $\mathrm{O}$ mundo, transformado em deserto, chora:

[...] l'heure est passée; après l'heure, le soir aussi est passé, et moi jarriverai trop tard. Jéhovah nia plus de fils; moi, je n’ai 
plus ni palmier, ni compagnon. Jéhovah est

seul au firmament; moi, je suis seul sur ma

grève: nos deux déserts se joignent, et ils

s'attristent l'un l'autre. Tous deux nous

roulons dans notre immense ennui, sans y

trouver de rivage: nous ne rencontrons,

nous n'entendons que nous. Nos deux échos

se rassemblent. Demain, quand il passera,

comme un arabe qui cherche son butin, si je

lui demande: où est ton fils? Il me

répondra: et toi, où est ton ombre? ${ }^{\text {17 }}$

Na terceira jornada, a mais longa e intitulada a "Morte", Quinet dispõe, ao lado do judeu errante, a personagem Raquel, igualmente dotada de imortalidade, portanto habilitada a atravessar os séculos, e Mob, figurando a morte. Os três percorrem o período medieval e o começo dos tempos modernos, mas a tristeza e desolação continuam. No interior de uma vila, à beira do Reno, Ahasvérus conhece Raquel e com ela o amor, e a possibilidade da consolação na poesia. Aqui, o estilo romântico de Quinet atinge personalidade e maturidade. Mas a exaltação dos sentimentos não é jamais assumida como plenitude, na medida em que vem acompanhada por uma enorme melancolia e por um vazio diante da vida: Mob, a morte, interfere nesses momentos fazendo refluir os sentimentos, em direção a um ceticismo irônico. A desolação atinge seu ponto culminante quando, na Catedral de Estrasburgo, Ahasvérus e Raquel assistem a uma liturgia macabra: uma dança dos mortos, na qual reis, papas e arcebispos desmascaram Cristo como um impostor, como aquele que nunca foi encontrado nem ressuscitou: "não há Cristo, nem Jesus de Nazareth, dizem, apenas a eternidade, vazia, o silêncio e a morte".

Novamente a narrativa é interrompida por outro entreato no qual o autor louva a poesia, reconhecendo o sofrimento do poeta que, com a "alma pesada e sangrando", lamenta não poder encontrar as palavras exatas que realmente exprimam a dor sentida, o desespero pela sensação de vazio que decorre do silêncio dos deuses e da insuficiência do mundo. Finalmente, há a quarta e última jornada intitulada o "julgamento final". Ali, o pai eterno e Cristo apresentam-se unidos no papel de Juiz, responsáveis pelo julgamento do mundo. Tudo e todos são julgados: oceano,

17 Idem, p. 132 
animais, montanhas, cidades, papas, reis, Napoleão, a ciência, as mulheres; seus lamentos são ouvidos, e, ato contínuo, perdoados, em um resumo sagrado da história do mundo. Finalmente, Ahasvérus é confrontado com o Cristo e julgado. Contudo, se de um lado, pela mediação do amor de Raquel, Ahasvérus sucumbe, reconhece a divindade de Cristo, pede perdão pela dúvida inicial e aceita o perdão e a misericórdia; de outro, o julgamento o liberta da religião. O Julgamento final é mais do que o pronunciamento de uma sentença judicativa, ele é um acerto de contas de Ahasvérus, e do próprio Quinet, com a história do cristianismo. A maldição de Ahasvérus muda de sinal, ganhando uma conotação positiva: ele na verdade havia sido enviado não como maldito, como errante, mas como consolador, com a missão de, após a passagem de Cristo, recolher a dor do mundo e anunciar a utopia. Ahasvérus, "cest l'esprit enfiévré qui cherche à travers l'ombre le soleil qui va venir".

O sofrimento foi recompensado, ao final, com a redenção; o sacrifício divino desdobra-se em humano, e o humano transmuta-se em divino, dissolvendo oposições. Ahasvérus, convertido de vítima em herói, nos versos finais de Quinet, transforma o medo da solidão em desejo de infinito. Reabilitado, poderia escolher o que quisesse fazer dali em diante, mas ele não quer retornar à sua pátria, nem repousar à sombra de uma vida burguesa convencional. Como os deuses, ele tem sede de infinito, quer a imortalidade, continuar errante, retomar a viagem, sem destino, caminhando sempre para o alto, para o futuro, para a eternidade. De judeu errante maldito, Ahasvérus torna-se um homem novo, um "segundo Adão", simbolizando, nesse momento, o destino de toda a humanidade que quer desdobrar-se em direção ao ilimitado. O cristianismo, como religião positiva, completa sua missão histórica, perdendo completamente sua razão de ser. Raquel acompanha Ahasvérus na nova viagem, que representa uma nova reconciliação entre infinito e finito, entre céu e terra. O mundo pede e está pronto para uma regeneração, para o recomeço, para a revolução, em um forte apelo mítico. Ao final, Quinet anuncia sinais de uma nova religião, mas como ela ainda não surgiu o futuro está em suspensão; a eternidade e o nada terminam, no epílogo, dialogando com um Cristo solitário, órfão, que encerrou sua tarefa, que não sabe mais ao certo qual era. Neste momento o que restava do mundo desmorona, em imagens de grande efeito visual, de pura materialidade, restando apenas a dor, o suspiro, a lágrima; a eternidade e o nada.

Ahasvérus pode ser nomeado "epopeia simbólica” ou drama épico. A obra é moderna, justamente por assumir uma estrutura formal que combina narrativa histórica, no sentido largo e poético do termo, com um ensinamento edificante vivido de forma dramática por meio de uma experiência íntima. Ora, a confluência do épico 
e do dramático não é original em Quinet, uma vez que Vigny já experimentara tal aproximação, o que teria influenciando provavelmente Quinet..$^{18}$ No entanto, o que marca a obra em questão é uma combinação de uma filosofia da história entristecida com um espiritualismo humanitário que crê na capacidade regeneradora do homem; na grandeza de um destino coletivo, isto é, na possibilidade criativa da revolução. Assim, se de um lado a trajetória errante de Ahasvérus parece apontar um percurso individual, de outro, a condução e desdobramento da narrativa possibilitam que o elemento individual seja simbolicamente transfigurado em universal, particularmente no julgamento final que atinge toda a natureza, povos e cidades.

Por meio de um naturalismo radical, entre uma forma de panteísmo e ousada heresia, Quinet dá voz a todo o universo: astros, rios, montanhas e seres da natureza; bem como aos mitos e lendas, demônios e críticos. As vozes cristãs são misturadas às pagãs; o humano dialoga com o titã, os anjos e as fadas com os demônios. Um conjunto que de fato encena uma história do mundo caótica e desarrumada, para justificar a necessidade da dissolução e projetar no futuro a recriação de um novo mundo, evidentemente melhor que o precedente. Para Bénichou, trata-se de uma obra estranha que se organiza em torno dos temas religiosos, mas apenas para serem ultrapassados e negados. Há em Ahasvérus uma dialética que lentamente substitui o tema cristão do mal e da missão redentora de Cristo, pelo tema da dor humana e pela promessa de uma sociedade que supere a noção de pecado e culpa; uma celebração da ruína do cristianismo histórico, ${ }^{19}$ mas não de suas promessas.

A literatura enuncia com seus próprios recursos a condenação do cristianismo como religião positiva, que será o tema central das futuras intervenções anticlericais de Quinet e de Michelet na década de 1840. Mas aqui no lugar de uma hostilidade aberta, Quinet figura o movimento de nascimento e morte do cristianismo, confirmando o valor histórico e, portanto, relativo das religiões. Por outro lado, a importância que o autor concede ao Oriente já demonstra uma tendência que se tornará cada vez mais clara em Quinet, principalmente a partir de 1841, com o surgimento de Le génie des religions. Para ele, a Europa seria regenerada pelo Oriente; a singularidade

"Meditar e conceber um pensamento filosófico, encontrar nas ações humanas os exemplos mais pertinentes, reduzir tal pensamento a uma ação simples que se possa gravar na memória, representada de alguma forma em uma escultura e um monumento grandioso à imaginação dos homens: eis o que deverá atingir a poesia ao mesmo tempo épica e dramática." VIGNY, Journal, 20 de maio de 1829, citado por BÉNICHOU, Paul. Le sacre de l'écrivain, op. cit., p. 356. Cf. a análise marxista sobre a confluência histórica entre o épico e o dramático em G. Lukács, Le roman historique, op. cit., p. 153-89.

19 BÉNICHOU, Paul. Le temps des profhètes. Doctrines de l'âge romantique. Paris: Gallimard, 1977, p. 465.

298 - SILVA, Arlenice Almeida da. Edgar Quinet e o romantismo 
dessa renascença oriental consistia em associar orientalismo com medievalismo, no intuito de contrabalançar a forte influência da tradição clássica. Victor Hugo no prefácio das Orientales, sua ode militante em favor da causa grega, não teria também afirmado: "au siècle de Louis XIV, on était helléniste, maintenant on est orientaliste"? $\mathbf{O}$ romantismo de Quinet enfrenta criticamente o coração do pensamento cristão, mas continua alimentando-se do mito da queda, redenção e emergência de uma nova experiência, ou seja, da ideia do paraíso restaurado. Como em Rousseau, apesar do tom cada vez mais cético, a literatura de Quinet continua pensando em uma origem fundadora, num paraíso redivivo e na possibilidade de refazer o mundo simbolicamente. Contudo, paradoxalmente, o modelo da busca das origens serve como ponto de partida para a afirmação da historicidade, uma vez que a pesquisa pela origem em Quinet possibilita ao historiador refazer poeticamente a ligação rompida entre natureza e história.

Em 1836, surge um poema heroico dedicado a Napoleão Bonaparte, encarado como o novo prometeu dos novos tempos. Se Ahasvérus é, nos termos do próprio Quinet, a "poesia do passado, e de toda a história", que figura "um homem eterno que contém em si todos os outros e a humanidade", Napoléon é a "poesia do presente" e seu herói é o indivíduo moderno. ${ }^{20}$ Trata-se de uma nova tentativa de Quinet de constituir um épico moderno. Mesmo tendo se tornado, nos anos seguintes, um inimigo do segundo Napoleão, Quinet não renegou nesta obra o primeiro, considerando-o um agente providencial modernizador da sociedade europeia. Quinet seguidamente sustentava que a França tinha um papel de liderança política e cultural diante das outras nações. E Napoleão, a seu ver, teria sido o arauto dessa tendência.

No trabalho que serve de introdução ao poema, intitulado "La poésie épique”, Quinet realiza sua melhor reflexão estética, recuperando a atualidade do gênero ao articular a relação entre a epopeia e a história em nova chave temporal. Ele recusa de pronto a ideia corrente de que o espírito francês seria impróprio para o épico, pois destituído de dimensão heroica. No lugar, procura traçar um panorama histórico, mostrando como a França medieval foi fonte de acontecimentos gloriosos, fornecendo material para a literatura épica, fase depois negligenciada pelo classicismo dominante no século de Luís XIv. A Henriade de Voltaire teria sido uma tentativa isolada de retomar essa forma, no século XVIII, por isso mesmo fadada ao fracasso. Definindo o gênio heroico de uma dada época pelo sentimento que uma nação tem dela mesma e de sua ação no mundo, Quinet percebe uma evolução da epopeia relacionada com a evolução da humanidade.

20 Napoléon, <http://gallica.bnf>. 
Ao afirmar a atualidade do épico, contudo, Quinet remonta ao tema central da estética moderna, de Goethe a Hegel, ${ }^{21}$ isto é, a diferença entre o lírico, o épico e o drama. Como F. Schlegel, Quinet localiza na história a diferença entre os gêneros, ${ }^{22}$ mas procura ressaltar e encontrar ao mesmo tempo o momento originário, isto é, a natureza primeira da separação. Assim, o épico emanaria da poesia lírica dedicada à ideia de Deus, mas figuraria cada vez mais o momento de secularização do mundo e de seus conflitos. Contudo, pela proximidade com o instante criador, nele ainda se sente a presença do divino, a "mão da providência", a presença do "maravilhoso". Diferentemente da poesia dramática que assume o ponto de vista individual, o poder do acaso e da fatalidade, as contradições e conflitos. Ou seja, na estrutura épica busca-se a inteligência universal - não pela presença divina, mas no pensamento do divino; a imortalidade e o eterno. ${ }^{23}$

Uma das primeiras elaborações modernas do problema do gênero surge com Goethe e suas três "formas naturais de poesia"(Naturformen). Goethe estabelece uma oposição entre as formas naturais de poetizar (Dichtweisen) e os gêneros poéticos derivados dessas formas (Dichtarten); ou seja, entre as atitudes do poeta - no épico, narrar claramente, no lírico, ser transportado pelo entusiasmo, no drama, agir pessoalmente - e as formas decorrentes e contingentes como o romance, a balada, ou a sátira. Cf. "Notes et dissertations au sujet du Divan oriental-occidental" in GOETHE, J. W. Écrits sur l'art. Paris: Klincksieck, 1983, p. 99-122. O idealismo alemão, notadamente Hegel, em sua Estética, teria esclarecido pela primeira vez a relação sugerida por Goethe ao destacar a seguinte oposição filosófica e histórica: o épico figuraria a "totalidade dos objetos", enquanto ao drama caberia a "totalidade do movimento". O romance seria a epopeia burguesa moderna, "um momento em que vemos reaparecer o pano de fundo de um mundo total e a descrição épica dos acontecimentos". Cf. HEGEL. Estética. Lisboa: Guimarães Editores,1993, p. 598. É interessante comparar a reflexão estética de Quinet com o pensamento alemão, especialmente o de F. Schlegel. Quinet não o cita, mas sabemos que ele era a referência inicial de muitos autores, em particular sua investigação sobre as condições de possibilidade de uma teoria dos gêneros de base historicista. Schlegel foi um dos primeiros a defender que os gêneros poéticos não valem para a poesia moderna, só para a clássica, e a sugerir uma sucessão histórica das formas: epopeia, tragédia, filosofia, romance. Cf. SZONDI, Peter. Poésie et poétique de l'idealisme allemand. Paris: Gallimard, 1974.

23 Cf. HUGO, Victor. Do grotesco ao sublime - O prefácio de Cromwell. São Paulo: Perspectiva, 2002. A mesma sucessão de formas está presente no texto de Hugo, de 1829, no qual ele sugere uma explicação para sua própria evolução literária, que caminhou do lirismo ao drama. Hugo retoma a ideia de uma evolução literária universal, que se inicia com a idade lírica. O lirismo seria a linguagem espontânea de homenagem dos primeiros homens ao seu criador, seguida de uma idade intermediária teocrática e militar, na qual predomina o épico, e que culmina, na idade moderna, com o predomínio do drama. "A poesia nascida do cristianismo, a poesia de nosso tempo é, pois, o drama; o caráter do drama é o real; o real resulta da combinação bem natural de dois tipos, o sublime e o grotesco, que se cruzam no drama, como se cruzam na vida e na criação. Porque a verdadeira poesia, a poesia completa, está na harmonia dos contrários." Idem, p. 46.

$300 \cdot$ SILVA, Arlenice Almeida da. Edgar Quinet e o romantismo 
Se há uma forma épica consagrada pela tradição na antiguidade, o estilo, contudo, não lhe é intrínseco, uma vez que esteve presente em várias épocas históricas, em uma pluralidade de figurações históricas, atuando com maior ou menor intensidade. De tal forma que o gênero não é exclusivo de um povo ou de uma época. Quinet designa, em suas anotações para uma história da poesia épica, três fases sucessivas com as pequenas variações na caracterização do sujeito épico: uma primeira fase religiosa, da Grécia até a Idade Média, a segunda, heroica, com Dante, Tasso e Ariosto, e a última, filosófica, na qual Quinet procura inserir-se. Nesta última fase, a epopeia moderna figuraria um novo sujeito que é, agora, o homem individual agindo num mundo em transformação, aberto para a renovação. Isso porque a Revolução Francesa legou ao mundo um "espetáculo" universal, impondo rupturas, alterando sensibilidades, instituindo uma nova época na qual a história se torna heroica, e os acontecimentos abrem uma nova via épica para a poesia. Se o gênero é histórico, a arte poética, que o acompanha, também deixa de ser normativa e atemporal, ganhando textura histórica. Para Quinet, o épico contemporâneo deveria figurar não um passado idealizado, mas a história contemporânea; ou seja, caberia à arte poética postular as novas relações desse mundo social com a produção artística. E, especificamente, figurar o dilema da contemporaneidade, que consistia, para Quinet, na elaboração formal de uma linguagem que fosse complexa o suficiente para abranger a simplicidade do elemento popular e a abstração do elemento filosófico da humanidade em transformação.

Assim, do ponto de vista formal, o gênero em língua francesa precisava ser revitalizado. Contudo, Quinet não inova como seria de esperar, mas opta pela tradição, combinando vários procedimentos utilizados no passado. Ora recupera o metro de doze sílabas, dos poemas carolíngios, ora o de oito sílabas, dos poemas do ciclo arturiano. Frequentemente usa rimas contínuas, para reforçar, ao mesmo tempo, a simplicidade, pela monotonia da repetição e a clareza da exposição, evitando os conflitos interiores e as obscuridades. Por último, em alguns momentos, como em Napoléon, o poema é pensado como um recitativo, um canto popular com melodia para, assim, efetivamente ressuscitar o uso original da epopeia. "É necessário que o poema seja ao mesmo tempo popular, como uma balada, ingênuo como uma criança, ponderado como o idoso; sem cessar de ser majestoso, ele deve ser sempre simples, e ornado sem ornamento." ${ }^{24}$ 
Em todo caso, para Quinet a poesia épica ganha na modernidade historicidade, ou seja, a história se impõe à arte. O que não significa que a arte se dissolva diante da história, pois, afirma Quinet:

[...] a poesia necessita mais da realidade que a história. [...] A epopeia não copia a história, ela não a contradiz, ela a transforma. Ela se ocupa das lembranças do mundo, como coisas eternamente vivas e lhes dá uma organização nova. O dever do historiador é o de se transportar ao passado e se identificar com ele; o do poeta é o de fixar o que não é mais em uma figura que é: imortalizar o passado, o presente e o futuro em um mesmo momento, que é o momento da arte. O historiador se apoia em um fato que foi e que não será mais, que não poderá ser um outro do que foi; o poeta se apoia sobre a tradição que é, que dura ainda, que se desenvolve em sua obra. Como nenhuma outra forma de arte, a epopeia contribui com a civilização, pois, ela mesma é a transformação contínua do passado no futuro, o espetáculo da vida em seu princípio e desenvolvimento. [...] Tudo que é efêmero e artificial está perdido para a epopeia. Ela só usa acontecimentos que levam a marca da necessidade e da vontade celestial. ${ }^{25}$

Contudo, se na epopeia antiga a presença do divino era essencial - uma poesia da providência -, na epopeia moderna figura o Gênio nacional, isto é, o sentimento que a nação tem de si mesma e de sua ação no mundo. "O poeta épico deverá representar agora não só o gênio nacional, mas refletir, combinando, o elemento popular e o elemento filosófico da humanidade moderna." ${ }^{26} \mathrm{Na}$ avaliação de Quinet, Napoleão é um exemplo de personagem épico moderno ao concentrar em si os valores de uma geração ${ }^{27}$ e uma fase de tendência democrática na França. "Muitas vezes pensei se não teria sido melhor morrer nas santas batalhas de 1814 e 1815, confessa Quinet, onde só se tratava na França da questão de todos e não de um só.”

Ora, Quinet, de fato, não enfrenta as relações cada vez mais perigosas entre literatura e nacionalismo, mas desloca a tensão para a oposição entre epopeia e romance; se não sucumbe à prosa do mundo, para usar a linguagem dos gêneros, é porque não reduz o épico ao romance. Para Quinet, a epopeia não deve refugiar-se no romance:

27 O herói moderno de Quinet assemelha-se ao conceito hegeliano de indivíduo histórico-universal (welthistorischen Individuen), aquele que resume em sua própria vida as determinações históricas da humanidade. 
Não podemos negar que o princípio da individualização desenvolveu-se muito nos tempos modernos, a epopeia rápida da vida interior e privada, que se nomeia romance, adquiriu uma importância que era desconhecida entre os antigos. Mas o poema heroico e o romance são duas formas de epopeia moderna da mesma maneira que a cidade e a família. A diferença entre o romance e a epopeia é a do homem e da humanidade. Há formas épicas, como os cantos populares, que o romance não pode resumir. ${ }^{28}$

Resta destacar que o debate de fato será enfrentado pela estética do século $\mathrm{xx}, \mathrm{o}$ qual pode ser resumido no diagnóstico de Robert Musil, em 1931, sobre a vitória do romance sobre a totalidade épica, ou seja, da inevitabilidade do "recuo do épico". A prosa por outro lado não favorece a reflexão filosófica. Para Quinet, a dimensão filosófica da épica moderna decorre da linguagem poética que possibilita ao poeta, na confluência entre imaginação e sensibilidade, ser o profeta do futuro ao apontar caminhos em épocas nas quais declinam os dogmas. Como em boa parte da literatura romântica, o filosófico se refere ao primado da ideia sobre o acontecimento, à redução dos acontecimentos históricos à sua ideia simbólica. A literatura - e a arte de modo geral - é, por esta razão, diferente da concretude histórica, na medida em que dialoga diretamente com o infinito. ${ }^{29}$ Contudo, apesar de definir o épico pela sua relação intrínseca com o eterno, Quinet não só recusa totalmente a estética católica que usa a arte para dar sustentação à religião, como exalta o divórcio entre arte e religião. Para ele o sentimento do belo não é de natureza exclusivamente religiosa, ou seja, ele não desperta apenas a intuição das realidades eternas. Em 1834, falando sobre os poetas alemães, Quinet defende:

Não digam que a poesia acabou, mas sim, sobretudo, que ela é a única que permaneceu viva. [...] nós caminhamos e vivemos não no que é, mas em uma fantasmagoria daquilo que deverá ser e será o amanhã. Por isso, a missão real do poeta é a de começar, sua vocação é a de ser o mediador dos povos que virão. ${ }^{30}$

28 Idem, p. 157.

29 Quinet defendia que sua literatura era fruto de imaginação e sentimento, "écrite avec le coeur", e ficava indignado com aqueles que viam nela uma metafísica ou a própria história. "Mon malheur est d'avoir écrit sur la Philosophie de l'Histoire. On est naturelement disposé à croire que je recommence ou continue ce travail, dans chaque ligne qui vient de moi." Citado por TRONCHON, Henri. Le jeune Edgar Quinet. Paris: Librairie les Belles Lettres, 1937, p. 3.

30 Citado por BÉNICHOU, Paul. Le sacre de l'écrivain. Doctrines de l'âge romantique, op. cit, 1977, p. 489. Anunciando o advento de uma era prosaica, Stendhal afirmou em 1802: "À medida que o gênero humano 
Como crítico, Quinet procurava interferir de forma propositiva nas discussões literárias da França, mas não "poetizar a vida política", como alguns românticos. Ao contrário, movido pelo olhar do historiador-filósofo, critica a literatura pretensamente nacional de sua época, fortemente marcada por proposições ambíguas. Em todo caso, o que Quinet encontra na produção que sai da Revolução Francesa é o contrário do que defende para o épico moderno: uma literatura alimentada por um "espírito de reação", pela condenação da revolução política e filosófica, por um vazio moral de que o Génie du christianisme de Chateaubriand ${ }^{31}$ é um marco inaugural. A revolução extenuada é repudiada e as ideias emancipadoras, afastadas. "A guerra declarada às revoluções, às inovações, num horror religioso de toda novidade, todo progresso, de toda a ousadia do espírito [...] e o véu da Igreja que nos cobre de alto a baixo e nos envolve no santuário gótico, do qual não se pode sair." ${ }^{22}$ Uma literatura que, segundo Quinet, confunde os tempos históricos, "descreve um cristianismo que não existiu em nenhuma parte", desorienta e confunde pela mistura de temporalidades, enfim, figurando heróis incapazes de agir, "René não fará nada de seu catolicismo, ele só é grande pelo seu imenso enfado", sustenta Quinet.

Se no século XVIII o escritor era a promessa de uma voz universal que aproximasse os homens em um projeto universal, o escritor do século XIX, ao anunciar o moderno, recusa tal papel, apegando-se aos detalhes e particularismos, em uma escrita que não mais se dilata. "A literatura, pouco a pouco, afirma Quinet, renuncia às ideias e sentimentos, pois eles são um obstáculo, e se fecha na forma e na cor, no colorido que não inquieta, nem escandaliza, em um terreno neutro onde a vida é cômoda." Em Prométhée, 1838, temos sinais mais evidentes de uma crise que, nesse aspecto, podemos nomear de antirromântica: a revolta aqui figurada é contra os deuses. Quinet transforma o Prometeu acorrentado, de Ésquilo, ${ }^{33} \mathrm{em}$ um profeta que anuncia o fim do politeísmo grego e o advento de uma nova religião; deformando o mito, Prometeu seria um precursor pagão de Jesus. No fundo, as religiões sabem agora que são mortais, históricas, e o próprio cristianismo reconhece seu declínio, e a dúvida reinante evidencia que pode surgir uma nova religião, do embate entre os homens e

amadurece, nos tornamos menos ingênuos no que fazemos, e consequentemente, menos poetas". Stendhal. In: BÉNICHOU, Paul. Le sacre de l'écrivain, op. cit., p. 322. Prometeu rebelde e insubmisso aos deuses. 
os deuses. Ou seja, o novo deus será criado pelo homem, será um elemento de união entre os homens, um novo símbolo. Eis o sentido do heroico em Quinet, fortemente influenciado por Vico e seu conceito de "Mente Heroica". ${ }^{34}$ Assim, enquanto espera pelo novo, a epopeia moderna deverá ser a epopeia dos homens, sem, contudo, perder sua dimensão sagrada.

A partir dos anos 1840 a relação de Quinet com a literatura se inverte. Ele interrompe as experiências ficcionais, privilegiando escritos históricos e filosóficos, mas irá retomá-las no exílio (1851-70), para provocar o debate estético do Segundo Império, com a ultrajante e engajada provocação: "Qual é o dever do escritor em uma época de decadência?". Enquanto Baudelaire e outros ironizam a perda da aura, figurando o fugidio, o instável, o circunstancial e a banalidade da vida cotidiana, em uma estética moderna que busca captar a "beleza passageira e fugaz da vida presente", ${ }^{5}$ Quinet insiste em definir o moderno em diálogo com o antigo, com o heroico, naquilo que este tem de eterno. ${ }^{36} \mathrm{Em} 1852$ ele publica, no exílio, um poema dramático, em cinco atos e em alexandrinos, intitulado Les esclaves, sobre a revolta dos gladiadores romanos. O clima dessa alegoria contemporânea é o da decadência e desilusão; Quinet denuncia a falta de heroísmo e a inutilidade da revolta dos escravos. E em 1860, surge Merlin, l'enchanteur, narrando a história do profeta Merlin, mas transposta para um tempo indefinido. Um romance que mistura elementos líricos e épicos e que busca "abrir novas vias para a imaginação" explorando as tradições nacionais e populares. Estas duas últimas tentativas literárias revelam, no entanto, esgotamento e fragilidade estilística. Contudo, ainda denunciam ou anunciam a crise do Segundo Império. Além do tema da decadência, Quinet aponta para a falta de heroísmo dos novos tempos. Como podemos ver em sua crítica histórica, o heroísmo em Quinet não é jamais pensado no plano individual, mas no coletivo, no espaço simbólico que aproxima os homens. Paralelamente podemos enxergar na poesia épica de Quinet

Cf. NAVET, George. La décadence et l'esprit héroique. In: MONNET, Roland (Org.). De la modernité d'Edgar Quinet. Paris: EDIMAF, 2002, p. 136-7.

35 BAUDELAIRE, 1995, p. 881.

36 Dolf Oehler, ao acentuar o caráter marginal da estética antiburguesa e revolucionária de Baudelaire, sustenta que a crítica de sua época foi incapaz de localizar nele o poeta dos novos tempos, na medida em que só o concebia de acordo com o parâmetro clássico-homérico. "A burguesia insistiu em temas clássicos, formas clássicas, modos de percepção clássicos e no heroísmo clássico. A única inovação que ela indicou aos artistas foi a substituição do pathos feudal por um pathos burguês. Isso, porém, era exigir muito de uma época em que esse pathos já havia perdido toda a credibilidade." OHELER, Dolf. Quadros parisienses. São Paulo: Companhia das Letras, 1997, p. 31.

Teresa revista de Literatura Brasileira [12|13]; São Paulo, p. 287-306, 2013 • 305 
este mesmo fundo, o tema da morte gloriosa. O vazio insuportável da morte vã, sua inutilidade e insignificância: eis o que Quinet procura preencher com seus versos. O estilo grandioso de Quinet procura esconder a estranheza incompreensível diante da morte anônima e do sofrimento inútil, que se fazem acompanhar quase sempre pela falta de horizonte e impossibilidade de futuro. A literatura épica, com seus elementos de regeneração e consolação, é assim nele o poder espiritual dos tempos nos quais declina o heroísmo.

Mesmo abordando temas religiosos, a estética de Quinet não se encerra no esteticismo e pode chamar-se de romântica só no sentido de tentar recolocar em termos laicos a relação simbólica da religião com a arte. A regeneração que defende está colocada no futuro e não no passado. Quinet fala sempre em regeneração, não em resignação. No fundo, sua dicção romântica combina uma consciência artística dotada de um forte poder imagético com uma consciência histórica, participando, a seu modo, do debate sobre os limites e possibilidades da poesia que já começa a ser chamada de moderna.

Se a obra de Quinet merece ser recuperada, a sua literatura deve ser praticamente ressuscitada, pois ela foi totalmente esquecida, eclipsada pelos grandes nomes da literatura francesa, como o de Victor Hugo. O público de sua época não a compreendeu, especialmente porque os exercícios narrativos de sua literatura apontavam de forma sistêmica para sua produção histórico-filosófica e militância anticlerical. Entendendo a dimensão simbólica da linguagem, isto é, sua capacidade de produzir realidade e não apenas designar objetos, criando assim seu próprio mundo significativo, Quinet estruturou um conhecimento a partir da reconstituição das matrizes simbólicas. Tal procedimento conjugava o apelo a uma nova religião com o heroísmo moderno que ele enxergava ter sido desperdiçado durante a Revolução. Ou seja, Ahasvérus antecipava poeticamente a interpretação polêmica de Quinet sobre o fracasso da Revolução Francesa. O tema do sagrado é, portanto, a chave que possibilita a compreensão da verdade da Revolução, que a literatura, através da figura do deserto vazio, denuncia como ainda não realizada.

Arlenice Almeida da Silva é professora da Universidade Federal de São Paulo, Campus Guarulhos. É autora de As guerras de independência (Ática, 1995); O jovem Lukács: a superação da estética, in: del roio, Marcos (Org.) Fyörg Lukács e a emancipação humana (Boitempo, 2013), entre outros. 